\title{
Comparison of a novel real-time RT-PCR, NS1 antigen detection and serology in early diagnosis of dengue in travelers
}

Eili Huhtamo

From $16^{\text {th }}$ International Symposium on HIV and Emerging Infectious Diseases

Marseille, France. 24-26 March 2010

\section{Background}

The increased traveling to dengue endemic regions and the numerous epidemics have led to a rise in imported dengue. The laboratory diagnosis of acute dengue requires several types of tests and often paired samples are needed for obtaining reliable results. Although several diagnostic methods are available, comparative data on their performance are lacking. The aim of the study was to compare the performance of novel methods including a novel pan-DENV real-time RT-PCR and a commercially available NS1 capture-EIA in regard to IgM detection for optimizing the early diagnosis of DENV in travelers.

\section{Methods}

A panel of 99 selected early phase serum samples of dengue patients was studied by real-time RT-PCR, NS1 antigen ELISA, IgM-EIA, IgG-IFA and cell culture virus isolation.

\section{Results}

The novel real-time RT-PCR was shown specific and sensitive for detection of DENV-1-4 RNA and suitable for diagnostic use. The diagnostic rates using combination of RNA and IgM detection were higher than when using NS1 and IgM detection. The results of RNA and NS1 antigen detection disagreed in some samples that had only RNA or NS1 antigen detected.

\section{Discussion}

The diagnostic rates of early samples are higher when either RNA or NS1 antigen detection is combined with

\footnotetext{
Correspondence: eili.huhtamo@helsinki.fi
}

University of Helsinki, Helsinki, Finland
IgM-detection. Additionally, DENV RNA and NS1 antigen detection methods provide accurate diagnosis as they are DENV specific diagnostic methods unlike serological methods that are voulnerable to cross-reactions caused by related flaviviruses. Besides the differences in the RNA and NS1 detection assays, the observed discrepancy of the results in some samples that had only RNA or NS1 antigen detected, could suggest individual variation or differences in timing of these markers in patient serum.

Published: 11 May 2010

doi:10.1186/1742-4690-7-S1-P185

Cite this article as: Huhtamo: Comparison of a novel real-time RT-PCR NS1 antigen detection and serology in early diagnosis of dengue in travelers. Retrovirology 2010 7(Suppl 1):P185.
Submit your next manuscript to BioMed Central and take full advantage of:

- Convenient online submission

- Thorough peer review

- No space constraints or color figure charges

- Immediate publication on acceptance

- Inclusion in PubMed, CAS, Scopus and Google Scholar

- Research which is freely available for redistribution

Submit your manuscript at www.biomedcentral.com/submit
C Biomed Central 